Int. J. Dev. Biol. 49: 79-83 (2005)

doi: $10.1387 / \mathrm{ijdb} .041944 \mathrm{cg}$

\title{
L'École de Nogent: the contributions of Etienne Wolff and Nicole Le Douarin
}

\author{
CHARLES GALPERIN*
}

\begin{abstract}
We retrace here the foundation of the "Nogent School". What were its main scientific orientations? Two fields of research dominated Etienne Wolff's work: Experimental Teratology and Intersexuality. Nicole Le Douarin's work, in one sense, started with a remarkable tool which is the quail / chick marker system. She applied this system to the study of in vivo migration of cells during embryonic life, i.e.neural crest cells and lymphoid progenitors. This article revisits some of these fundamental aspects.
\end{abstract}

KEYWORDS: experimentalteratology, intersexuality, migration, differentiation, neuralcrest, Quail/Chick

The scientific premises of the "Ecole de Nogent" are located on the border of the bois de Vincennes, near Paris. For an epistemologist, it is a priviledge to outline the birth of this institution, the evolution of its scientific goals and the advances it brought to the field. Why do I call it "Ecole de Nogent"? According to historian Jean Gayon, who attributes a technical meaning to the term regarding scientific research, a school born from institutional circumstances provides a matrix in which creative work "shapes new concepts and methods". It is the role of history and epistemology to describe the founding landmarks of such a school.

Research goals in an institution like this have to be set by an inspired scientist. Two leaders, who pursued common theoretical aims, stimulated investigations successively in Nogent, imported and, more importantly, designed novel experimental techniques. Clarity in spoken and written communication and shrewd interpretation prompted international recognition.

Etienne Wolff (Fig. 1), elected Professor at the Collège de France in 1955, created in Nogent-sur-Marne the "Institut d'Embryologie Expérimentale et de Tératologie du CNRS (Centre National de la Recherche Scientifique) et du Collège de France", which opened its doors in 1960.

Nicole le Douarin (Fig. 2) succeeded him as the head of the Institute in 1974 and renamed it "Institut d'Embryologie Cellulaire et Moléculaire", thus acknowledging the evolution of the field. At that point it had truly become a school. For half a century, French and foreign visiting scientists as well as students have regularly published innovative data. The Institute, entirely dedicated to fundamental research, has initiated several generations of young scientists to both concepts and techniques with constant drive.

The laboratory in Nogent was preceded by Wolff's in Strasbourg and Le Douarin's in Nantes. I shall sketch here the course of events that initiated this "Ecole" still on the move.

\section{Etienne Wolff and experimental teratology. A glance into the Spemann School}

In 1932, Etienne Wolff undertook research in experimental embryology under the guidance of Pr. Ancel. "Embryology", at that time called "developmental mechanics" as E. Wolff used to say, exploited the experimental approach. Concerning teratology - the science dedicated to the origins of malformations - E. Wolff estimated that it had not appreciably progressed since Dareste (1822 - 1899), in spite of Hans Spemann's investigation in 1903.

The idea of embryological mechanics resulted from the work of Wilhelm Roux (1850 - 1924) published in the Archiv für Entwicklungsmechanik der Organismen, "mechanics" meaning the analytical study of primary causes of embryonic development. Without thoroughly relating Roux's notion of "mosaic" eggs in amphibians, two concepts should be recalled: the first is about autodifferentiation of embryonic parts and the second about external factor-dependent differentiation. In 1881, Hans Driesch (1867 - 1941) illustrated the concept of regulation during early development, by separating the first two cells - or blastomeres from the sea urchin egg. Each blastomere gave a whole embryo. This shortly summarized context is the one in which Hans Spemann's (1869-1941) teratological research, published in 1903, developed.

Working on an early salamander embryo, Spemann undertook constriction experiments, in which the first two blastomeres were not completely separated. He obtained duplications, i.e., organisms with two heads and one trunk. He wondered why partial constrictions only affected the duplications of forelimbs. Excepting his studies about lens formation (1910 - 1912), Spemann was mainly interested in the formation of organs along the axes of vertebrates; his conclusion was that organ rudiments become irreversibly determined during gastrulation.

*Address correspondence to: Dr. Charles Galperin. 33 rue Croulebarbe, 75013 Paris, France. e-mail: galperin.charles@noos.fr 


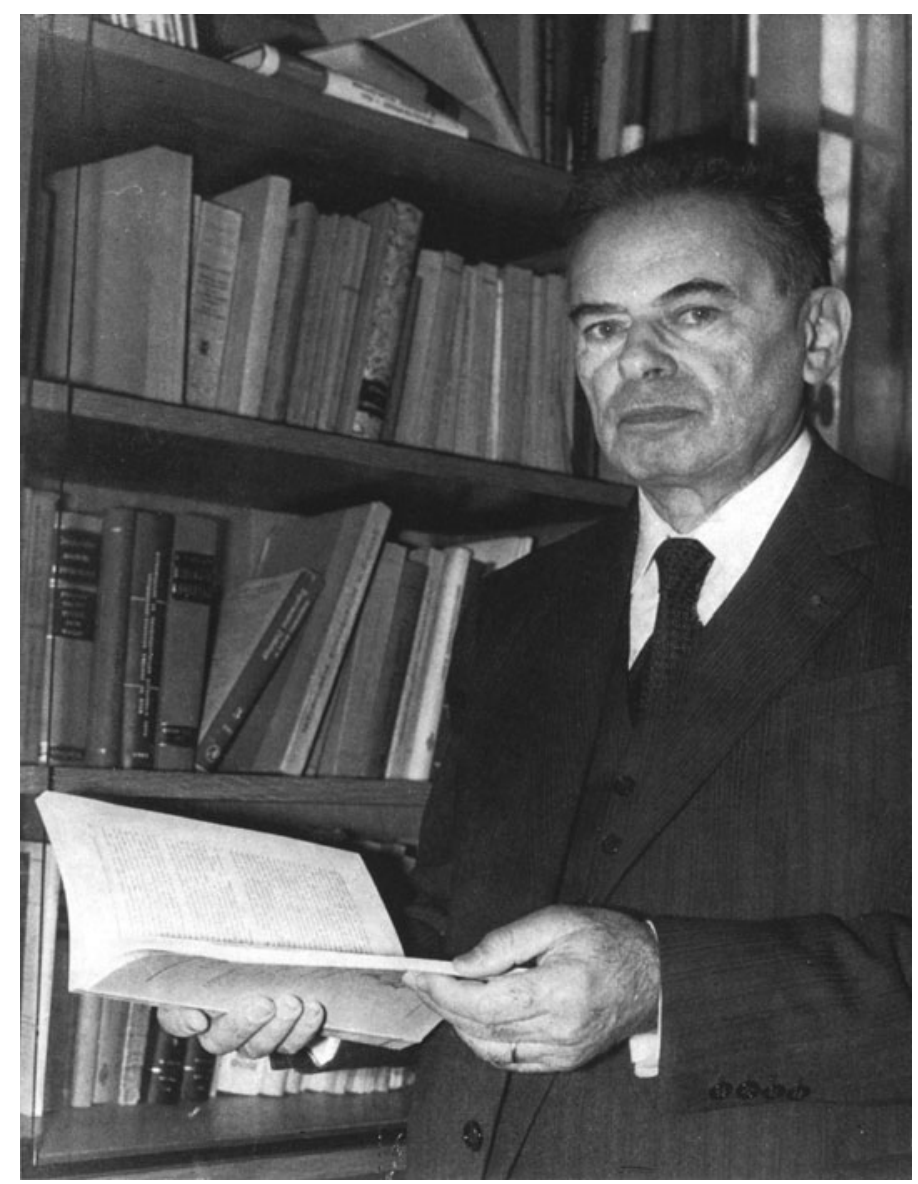

Fig. 1. Etienne Wolff.

Inspired by Ross G. Harrison (1870 - 1959), Spemann then used the technique of heteroplastic transplantation in the early gastrula. He used two species of the same genus, exploiting their differences as stable markers. One species is the unpigmented Triturus cristatus and the other is the pigmented T. taeniatus. In 1918, the upper lip of the blastopore was designated as the differentiation center. "The production of animal chimeras by heteroplastic transplantation between Triton cristatus and taeniatus" was published in 1921 (for more details, see Sander and Faessler, 2001).

This is how Spemann stepped from experimental teratology to embryonic induction. Spemann and his student Hilde Mangold (born Proescholdt) (1989 - 1924) introduced the concept of "organization center" applied to the upper lip of the blastopore and then the concept of organizer. In 1924, Hilde Mangold's experimental work was the basis for the crucial paper about "Induction of embryonic primordia by implantation of organizers from different species" (Spemann and Mangold, Int. J. Dev. Biol. 2001). The transplantation of the upper lip of the blastopore of $T$. cristatus into the ventral side of the gastrula of $T$. taeniatus induced a secondary neural plate and a secondary embryo alongside the first one. This discovery, made at Freiburg in Brisgau, has an enormous impact and was granted official recognition with the Nobel Price in 1935. In the meantime, E. Wolff, advised by his mentor, Paul Ancel, was reviving teratology.
In the case of upper vertebrates, at that time no results had ever succeeded in creating a specific monstrosity. This was the aim that Paul Ancel (1873 - 1961), Embryology Professor at the Medical Faculty of Strasbourg, set for Wolff's doctoral thesis, which was to be entitled: "An attempt to determine localized lesions on the germ of a chicken, in order to reproduce known spontaneous monstrosities".

"One could hope that in addition to teratological results, a method of localized lesions would clarify germinal localizations and evolutive potentialities which could be applicable to other territories. This might, some day, lead to a topographic map of anlagen, according to the model established by Vogt for the amphibian embryo. Underlining the fact that there are no fundamental differences between causal embryology and experimental teratology, the aim of new experiments in this perspective was to succeed in "producing purposely numerous malformations, to follow and study them from their origin, up to characteristic stages". Such a conception offered "almost unlimited possibilities" so that E. Wolff did not consider his thesis as final. On the contrary, Wolff saw it as "the introduction to and aim for novel research".

The main conclusions, discussed in the third part of his thesis, are the following "according to my experiments, it is now clear than monstrosities can result from external factors during development. The experimental malformations obtained by direct teratogenic methods are in every respect comparable to spontaneous monstrosities". In addition "teratogenesis offers the possibility to create still unknown types or variants such as anterior symelians and hemicyclops". Moreover, any embryo could be turned into predetermined teratological types. Three points emerged from this research:

1. From the studies on "symelia", E. Wolff concluded that "proper attention had not been given to the fundamental phenomenon which, in our experiments, is the arrest of axial organ development". He even set it as a law of teratogenesis. "The initial interference responsible for teratological development is to arrest development locally".

2. Teratological factors act on presumptive primordia, between the stage of determination and that of differentiation. This interpretation required to characterize precisely "indifferent" versus "determined" primordia. The first do not have an irrevocable destiny. The only positive indication about this property in a primordium is topographical position recognizable through vital markers; in normal development, the presumptive primordium of an organ is always located in the same territory of the embryo, hence only one potential is later achieved.

However, the transplantation experiments showed that the potential of undetermined primordia was multiple. As Wolff said, "a primordium presumed to be determined, even if it does not appear to be so, cannot be deviated from its destiny, even if transplanted or submitted to abnormal influences". Such determined primordia can be singled out, by means of either vital color markers or localized lesions.

3. Important "losses of substances are not repaired, there is no possible regulation".

The final conclusion was "that localized irradiations are a choice embryological method to determine the precise topography of presumed determined primordia and to follow their fate until an advanced stage of development". 


\section{Etienne Wolff's research on intersexuality}

Concerning this major aspect of Etienne Wolf's endeavors, we shall only quote part and mention a few questions, first going back to conclusions reached in the early $X X^{\text {th }}$ century:

"A good deal of research took place between 1895 and 1903 on normal and pathological testis, which led to the final conclusions of Bouin and Ancel, i.e., that interstitial tissue of the testis and the seminal structures are ontogenically and physiologically independent". The interstitial tissue had to be considered as an internal secretion gland with a glandular and morphogenetic function. Between 1904 and 1930, Bouin, Ancel and their collaborators were going to perform a number of experiments proving their hypothesis to be well founded.

In 1929, Adolf Butenandt crystallized the female hormone termed folliculin by Robert Courrier in 1924 - while simultaneously E. Doisy, C.D. Velen and J.-A. Thayer obtained the first preparation of crystallized folliculin (oestrone); in 1931, Leopold Ruzicka synthesized androsterone for the first time.

In 1935, the controversy launched by Bouin and Ancel was, in a sense, closed. Three communications showed that hormones were responsible for sex modification. A preliminary note of Etienne Wolff and Albert Ginglinger, entitled "On the experimental production of intersexuals by injections of folliculin performed on the embryo of a chicken", concluded: "In the chicken embryo, intersexuality can regularly be obtained by injecting folliculin to genetically male individuals, given that these injections are performed before the seventh day and that the dosage is about $100 \mathrm{IU}$ ".

After the war in 1946, E. Wolff resumed his work on intersexuality. According to Nicole Le Douarin "it had to be proven that the gonads of a bird embryo secrete sexual hormones or factors acting in a similar manner on sexual differentiation". The proof of this role in normal sex differentiation was brought about by castration experiments performed by Emilienne Wolff on the duck embryo.

Finally, E. Wolff and Katy Haffen gave a new twist to this research through organ culture of either the gonads or different parts of the genital tract: "we succeeded to cultivate in vitro whole gonads of chicken and duck embryos in a new environment. We asked whether the undifferentiated primordium of genital glands were going to differentiate in ovaries and testes as in the normal embryo, i.e., 'auto-differentiate sexually', in the way already determined organs do and whether they synthesized the factors necessary for their differentiation. We also asked whether sexual differentiation could be influenced by external factors".

E. Wolff had previously modified normal sexual differentiation either by means of injected crystallized sexual hormones (1935) or by the "secretions of embryonic gonads grafted into an embryo of opposite sex". Could the same effect be obtained in gonads which were isolated from the organism and cultivated in vitro? The authors showed that the factors responsible for in vitro differentiation resided in the pregonadal tissues. In this respect, three points should be emphasized. Firstly, E. Wolff remained faithful to the method used in his first research in experimental teratology. He used direct intervention to obtain the intersexuality of embryonic gonads. Secondly his investigations addressed the supra-cellular level. He was interested in dissociating and recombining the components of primordia or in associating fragments of embryonic organs, either homologous or heterogeneous and finally in performing xenoplastic associations. Embryonic organs from mice could be cultivated in the environment used for avian organs. This permissivity led Eitenne Wolff to write "if organs of birds and mammals tolerate the same environment, it is worth trying to associate them into a chimera". Hence the third point: the creation of chimeric organs which opened the way to in vivo chimeras, performed later between different species such as the quail and the chicken, or the mouse and the chicken.

Research in experimental teratology and intersexuality thus constituted the founding cornerstone of the Nogent School.

\section{From tissue interactions to cell migration: Nicole Le Douarin}

I wish to highlight the connection between Etienne Wolff's methods and interests and those of Nicole Le Douarin, who prepared her $\mathrm{PhD}$ thesis under his guidance and became the most prominent of his intellectual heirs.

The experimental method consisting in X-ray irradiation of the embryonic heart, devised by P. Ancel and E. Wolff in 1934, had yielded malformed embryos with extensive abnormalities of the heart and blood vessels.

In her early career, Le Douarin $(1961,1964)$ used the same methods in order to study the organogenesis of the gut and liver, again on the chick embryo. She also applied charcoal particles to mark specific areas of the primordial germ layers (see Le Douarin,

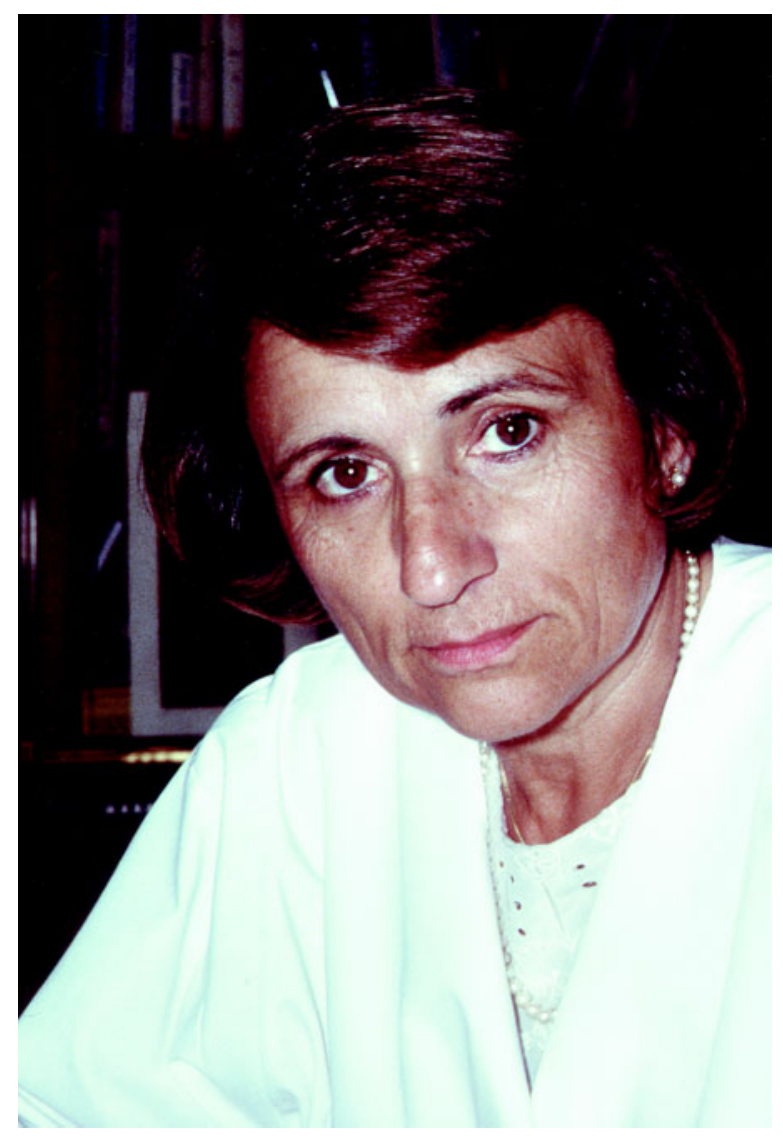

Fig. 2. Nicole Le Douarin. 


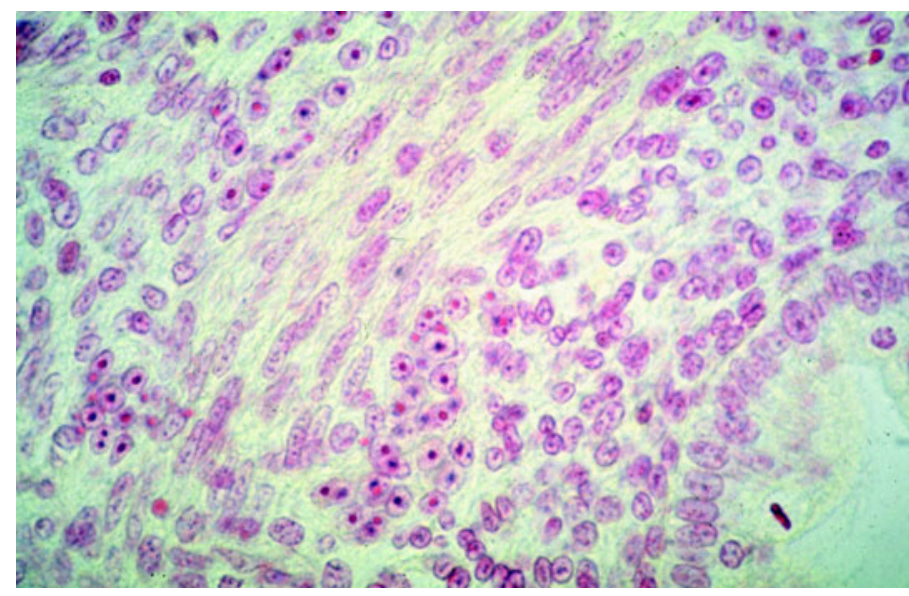

Fig. 3. Gut of a 'neural chimera', illustrating the quail marker after Feulgen DNA staining. Neural crest cells issued by the graft have given rise to the neural plexi (Auerbach's and Meissner's) in the host intestine. The quail cells arranged in two distinct concentric rings are recognized by the large red dot in their nucleus.

2005 in this issue). Liver organogenesis had not been previously studied experimentally. Her thesis was a landmark which clarified the morphogenetic interactions underlying liver development and today still serves as a reference necessary to understand the underlying genetic networks, that have recently begun unraveling.

As a side consequence of this study, Nicole Le Douarin became interested in the neural crest (having associated the liver endoderm to mesonephritic mesenchyme, she found that medulloadrenal cells differentiated in the combination) (see Le Douarin, 2005 in this issue). This transitory structure, evolution's innovation in vertebrates, became and still is one of Le Douarin's main themes of investigation.

How did she come to develop this novel scientific endeavour, which became in her wake that of so many scientists? This adventure began in the early 1970s in the "Laboratoire d'Embryologie de la Faculté des Sciences de l'Université de Nantes" where Le Douarin created a research unit which received the "CNRS associated team" label. The story began by combining quail mesoderm with chick hepatic endoderm, with the aim of determining whether tissue interactions could occur between germ layers from different species. During this particular experiment, Le Douarin became aware of the striking nucleolar difference between the two species. Cell labeling was a classical tool of embryology, particularly developed to analyze the early cell movements in the amphibian embryo by Vogt. No technique however offered durable labelling, so that cell migrations could be followed only very shortly.

Le Douarin decided to apply the quail-chick system to the study of in vivo migration in the case of cells, which were known to accomplish extensive migrations during embryonic life, i.e., neural crest cells (Fig.3) and lymphoid progenitors.

The remarkable corpus of data that were acquired by her team and by numerous others in the world in these domains concerning the development of the central nervous system, of the immune and hematopoietic system are reviewed in this issue, beginning with a personal account by Nicole Le Douarin of the many years she dedicated to Science. She highlights the memorable moments of these investigations and evokes the contribution of many long term or occasional collaborators.

She previously recorded more in-depth the aims and progress of her investigations, dwelling on the human aspects, in a book published by Odile Jacob in 2000 entitled "Des chimères, des clones et des gènes". Researches about the neural crest were on the other hand recorded in two monographs published in 1982 and 1999.

The other articles in this tome are either in depth reviews of specific themes or reports of original findings.

To conclude, I wish to emphasize that the activity in the Ecole de Nogent is characterized by a trait typifying research schools: experimental work has evolved around a central theme, as a continuum all along enriched by new ideas and techniques. The School of Nogent belongs to the history of Sciences but it is not a mausoleum, it lives, it teaches and it inspires.

\section{Acknowledgements}

I am deeply indebted to Nicole Le Douarin, Françoise Dieterlen and Marie-Aimée Teillet, as well as to Jean-Louis Fischer, Jean Gayon, JeanAntoine Lepesant, Jean François Nicolas, MichelMorange, M. Beaujean, and Françoise Thibault for their encouragement, help and advice.

\section{References}

FISCHER, J.-L. (1993). Histoire du déterminisme épigénétique du sexe chez les animaux et l'homme de 1800 à 1935. Thèse de doctorat d'Etat,Université de Paris, Panthéon- Sorbonne.

FISCHER,J.-L. (1994). Les recherches sur l'intersexualité expérimentale chez les vertébrés dans l'école française de l'entre-deux guerres. In Les sciences biologiques et médicales en France 1920-1950. (eds. Debru, J., Gayon, J., Picard, F.) Paris. pp. 171-175.

FISCHER,J.-L. (2000). Etienne Wolff (1904-1996), ses débuts, ses cahiers de laboratoire (1932-1938). Rev. Hist. Sci. 53: 447-474.

GALPERIN, C. (2002). L'Ecole de Nogent. Etienne Wolff et Nicole le Douarin. Bull. Hist. Epist. Sci. Vie. 9: 93-124.

GAYON, J.(1998). De l'usage de la notion du style en histoire des sciences. In $\mathrm{La}$ Rhétorique:enjeux de ses résurgences. (Eds. Gayon, J. Gens, J.C., Poirier, J.) Ousia.

HAMBURGER, V. (1988) The heritage of Exprimental Embrylogy. Hans Spemann and the Organizer. Oxford University Press.

LE DOUARIN, N. (1969) Particularités du noyau interphasique de la Caille japonaise (Cornutrix cornutrix japonica). Bulletin biologique de la France et de la Belgique 103: 435-452.

LE DOUARIN,N. (1982) The Neural Crest. Cambridge University Press.

LE DOUARIN, N. (1997) Etienne Wolff, un pionnier de l'Embryologie et de la Tératologie experimentale. Medecine / science 13: 685-694.

LE DOUARIN and KALCHEIM, C. (1999) The Neural Crest, 2nd Ed. Cambridge University Press.

LE DOUARIN, N. (2005) The Nogent Institute - 50 years of Embryology. Int. J. Dev. Biol. 49: 85-103. doi: 10.1387/ijdb.041952nl

SANDER, K. and FAESSLER, P.E. (2001) Introducing the Spemann-Mangold organizer: experiments and insights that generated a key concept in developmental biology. Int. J. Dev. Biol. 45: 1-11.

SPEMANN,H. (1903)Entwicklungsphysiologische Studien am Tritonei 3. Roux's Arch. f. Entw. Mech. 16: 551-631.

SPEMANN, H. AND MANGOLD, H. (2001) Induction o fembryonic primordia by implantation of organizers from a different species. Int. J. Dev. Biol. 45: 13-38 (Fresh reproduction and corrected translation of Über induktion von Embryonalanlagen durch implantation artfremder organisotoren, Archiv für Mikroskopische Anatomie und Entwicklungsmechanik, (1924) 100: 599-638. 
WOLFF, E. (1936) Les bases de la Tératologie expérimentale des vértébrés amniotes d'après les résultats des méthodes directes. Archives d'Anatomie,d'Histologie,et d'Embryologie,Strasbourg. Les éditions de la librairie "Union".

WOLFF, E. (1947).Recherches sur l'intersexualité expérimentale produite par la méthode des greffes de gonades à l'embryon de Poulet. Arch.Anat. Hist.Embryol. 36: 69-90.
WOLFF, E. and HAFFEN, K. (1952) Sur le développementet la différenciation sexuelle des gonades d'Oiseau en culture in vitro. J. Exp. Zool. 119: 381-399.

WOLFF, E. (1946) Les Changements de sexe. Gallimard, Paris.

WOLFF, E. (1948) La Science des monstres. Gallimard, Paris.

WOLFF, E. (1990) Trois pattes pour un canard,mémoire d'un biologiste. Fondation Singer-Polignac, Paris. 